\title{
PROSPEK PENGEMBANGAN TEKNOLOGI RADIASI SEBAGAI PERLAKUAN PENDAHULUAN BIOMASSA LIGNOSELULOSA
}

\author{
Harum Azizah Darojati ${ }^{1}$ \\ 1) Institut Agama Islam Negeri Salatiga, Salatiga, harumazizah@gmail.com
}

\begin{abstract}
ABSTRAK
PROSPEK PENGEMBANGAN TEKNOLOGI RADIASI SEBAgai PERLAKUAN PENDAHULUAN BIOMASSA LIGNOSELULOSA. Biomassa lignoselulosa yang terdiri dari selulosa, hemiselulosa dan lignin, kerap ditemui sebagai limbah, sebenarnya dapat dimanfaatkan melalui perlakuan pendahuluan. Perlakuan pendahuluan membantu pemanfaatan lignoselulosa dengan cara mengubah strukturnya sehingga mempermudah konversi selulosa dan hemiselulosa menjadi sumber gula yang dapat difermentasi. Berbagai metode fisik, kimia, biologis, atau gabungan digunakan untuk perlakuan pendahuluan lignoselulosa. Teknologi iradiasi adalah salah satu metode perlakuan pendahuluan yang unik dan menjanjikan, yang melibatkan aplikasi sinar gamma, berkas electron, radiasi microwave, UV dan ultrasonik. Ulasan ini menjelaskan peran dan prospek penerapan teknologi radiasi sebagai perlakuan pendahuluan dalam pemanfaatan biomassa lignoselulosa.
\end{abstract}

Kata kunci: lignoselulosa, radiasi, gamma, uv, berkas elektron, microwave, ultrasonik, perlakuan pendahuluan

\section{ABSTRACT}

PROSPECT OF RADIATION TECHNOLOGY DEVELOPMENT AS A PRETREATMENT TO LIGNOCELLULOSIC BIOMASS. Lignocellulosic biomass which is consisting of cellulose, hemicellulose and lignin, often found as waste, can be used through pretreatment. Pretreatments help to increase the use of lignocellulose by changing its structure so that it is easily converted cellulose and hemicellulose into a source of fermented sugar. Various physical, chemical, biological, or combined methods used for lignocellulose pretreatment. Irradiation technology is one of the unique and promising pretreatment methods that involves the application of gamma ray, electron beam, microwave, UV and ultrasonic radiation. This review explains the role and prospects for applying radiation technology as a pretreatment in the utilization of lignocellulosic biomass.

Key words: lignocellulose, radiation, gamma, uv, electron beam radiation, microwave, ultrasonic, pretreatment

\section{PENDAHULUAN}

Semakin berkembangnya teknologi dan industri menimbulkan produksi limbah yang semakin meningkat. Limbah ini dapat berasal dari banyak sektor seperti industri, kehutanan, pertanian, ataupun kegiatan rumah tangga. Pertambahan dari limbah ini dapat menimbulkan masalah lingkungan, kesehatan, keselamatan. Permasalahan ini mendorong penelitian dalam memanfaatkan limbah tersebut, contohnya adalah limbah yang termasuk ke dalam biomassa lignoselulosa. Biomassa lignoselulosa merupakan sebuah struktur kompleks yang tersusun dari mikrofibil-mikrofibil (serat) selulosa yang membentuk kluster-kluster (kelompok), dengan ruang antar mikrofibilnya terisi oleh hemiselulosa, yang terbebat kuat oleh lignin [1]. Biomassa lignoselulosa terdiri dari selulosa 
(39-45\%, hemiselulosa (15-38\%), dan lignin (18-36\%). Biomassa menyimpan sejumlah besar karbon sebagai polisakarida dan lignin yang dapat dimanfaatkan sebagai bahan baku terbarukanuntuk memproduksi bahan kimia dan bahan bakar [2].

Selulosa adalah senyawa organik dengan rumus $\left(\mathrm{C}_{6} \mathrm{H}_{10} \mathrm{O}_{5}\right)_{\mathrm{n}}$ yang merupakan komponen utama lignoselulosa. Selulosa merupakan polisakarida yang terdiri dari rantai linear (memanjang, tidak bercabang) dengan beberapa ratus hingga ribuan unit $\mathrm{D}$-glukosa terkait $[1,3]$. Pemanfaatan selulosa didahului dengan menghidrolisis selulosa menjadi glukosa, namun proses tersebut sulit dilakukan karena polimer selulosa saling menumpuk/terikat dan membentuk serat panjang yang sangat kuat $[4,5]$.

Hemiselulosa adalah sebuah grup polisakarida yang mengandung banyak monomer gula berbeda. Monomer gula ini dapat terdiri atas pentosa (xilosa, rhamnosa, and arabinosa), heksosa (glukosa, manosa, dan galaktosa), asam uronat, dan gugus asetil [4]. Seperti halnya selulosa, hemiselulosa perlu dihidrolisis menjadi xilosa untuk memanfaatkannya.

Lignin adalah struktur kompleks yang berada pada dinding sel primer, sebagai penyokong struktur lignoselulosa. Unit penyusunnya berupa polimer fenilpropan yang terdiri dari guaiasil, syringil dan $\mathrm{p}$-hidroksifenil yang dihubungkan oleh ikatan eter ( $\beta-\mathrm{O}-4)$, dan atau ikatan C-C [3]. Lignin merupakan salah satu faktor utama yang menyulitkan degradasi lignoselulosa dengan enzim. Selain lignin adalah hambatan utama untuk mengakses selulosa dan hemiselulosa, interaksi hidrofobik lignin dengan molekul enzim menyebabkan ikatan yang menurunkan kemampuan enzim menghidrolisis selulosa [7].

Masing-masing komponen lignoselulosa tersebut mempunyai manfaat yang besar, sehingga banyak penelitian dilakukan dengan tujuan pemisahan (fraksionasi), pemanfaatannya menjadi bahan kimia, polimer, etanol, pemanis alami, maupun resin. Limbah yang merupakan biomassa lignoselulosa diantaranya adalah tongkol jagung, rumput, bagas tebu, tangkai padi, kulit pisang, dan tandan kosong kelapa sawit. Komposisi tiap komponennya (lignin, hemiselulosa, selulosa) dapat berbeda-beda dan dipengaruhi oleh kondisi lingkungan, diantaranya adalah penyimpanan dan kondisi tanah tempat biomassa tersebut ditanam.

Proses pemanfaatan biomassa lignoselulosa ini umumnya diawali dengan perlakuan pendahuluan (pretreatment). Perlakuan pendahuluan ini dapat dilakukan dengan proses fisik, kimia, atau biologi. Perlakuan pendahuluan ini penting untuk mempermudah pemanfaatan biomassa lignoselulosa dengan adanya degradasi, dan perluasan akses ke dalam polimernya. Langkah kunci pemanfaatan biomassa lignoselulosa adalah mengatasi resistensi dinding sel terhadap dekonstruksi biomassa lignoselulosa. Resistensi ini diakibatkan oleh struktur kristal selulosa yang membentuk sebuah polimer matriks dari lignin dan hemiselulosa. Tujuan utama perlakuan pendahuluan adalah untuk memisahkan selulosa dari polimer matriks tersebut [8].

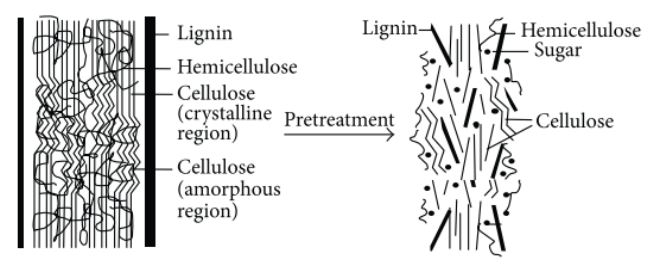

Gambar. 1. Efek perlakuan pendahuluan terhadap struktur lignoselulosa [9]

Teknologi perlakuan pendahuluan ini harus dapat mengonversi lignoselulosa menjadi bahan bakar atau bahan kimia dengan efektif. Teknologi ini harus memenuhi beberapa kriteria sebagai berikut meningkatkan pembentukan gula atau kemampuan pembentukan gula melalui hidrolisis menghindari degradasi atau kehilangan karbohidrat, menghindari pembentukan produk samping berupa senyawa inhibitor yang menghambat proses hidrolisis dan fermentasi, serta biaya operasi yang efektif. Hidrolisis enzimatik yang didahului dengan perlakuan pendahuluan mampu menghasilkan perolehan gula hingga sebesar $90 \%$. Hal ini berbeda jika diselenggarakan tanpa adanya perlakuan pendahuluan, yaitu hanya sekitar $20 \%$ dari gula yang dapat terhidrolisis. Saat ini, biaya perlakuan pendahuluan cukup signifikan di dalam proses konversi biomassa lignoselulosa, namun dengan peningkatan efisiensi dan penurunan biaya melalui penelitian dan pengembangan lebih lanjut, biaya perlakuan pendahuluan dapat ditekan Perlakuan 
pendahuluan dapat dilakukan secara fisik, kimia maupun biologi [6].

Salah satu proses kimia fisik yang dapat diaplikasikan sebagai perlakuan pendahuluan adalah teknologi radiasi. Teknologi radiasi ini memiliki beberapa keunggulan dibandingkan dengan teknologi secara fisik, proses dengan penambahan bahan kimia, dan dengan proses biologi. Kelemahan proses fisik yaitu proses ini hanya untuk memperkecil ukuran dan tidak mengubah struktur dan komposisi dari biomassa lignoselulosa sehingga memerlukan perlakuan lain. Sementara itu, proses perlakuan pendahuluan dengan penambahan bahan kimia akan menimbulkan kebutuhan daur ulang bahan kimia, pembuangan limbah, dan polusi ke lingkungan [10]. Kelemahan proses biologi adalah proses ini memerlukan waktu yang sangat lama, yaitu dalam hitungan minggu [6]. Keunggulan teknologi radiasi adalah tidak menimbulkan kebutuhan daur ulang, residu/limbah, polusi ke lingkungan, serta tidak membutuhkan waktu lama, bahkan hanya beberapa jam saja. Selain itu, teknologi radiasi ini dapat dikombinasikan dengan proses lain secara fisik, kimia maupun biologi.

Efektivitas dari iradiasi dipengaruhi oleh beberapa faktor yaitu frekuensi radiasi, lama paparan, komposisi biomassa, dan resistensi terhadap radiasi oleh media antara radiasi dan biomassa [9]. Beberapa teknologi radiasi sebagai perlakuan pendahuluan sudah banyak dikembangkan untuk bermacam-macam jenis biomassa lignoselulosa. Teknologi radiasi tersebut bertujuan untuk memberikan dampak struktural dan komposisi pada biomassa lignoselulosa. Tulisan ini mengupas beberapa teknologi radiasi dari sisi metode, efek dari perlakuan pendahuluan, tantangan, dan target penelitian di masa depan.

\section{METODE}

Kajian ini dilakukan dengan metode yang bersifat deskriptif, analitik, kuantitatif dan kualitatif melalui studi literatur dan pengamatan terhadap jurnal-jurnal terkait. Studi literatur diawali dengan pokok bahasan mengenai biomassa lignoselulosa, yaitu komponen dan manfaatnya. Selanjutnya, dilakukan studi mengenai konsep teknologi perlakuan pendahuluan terhadap biomassa lignoselulosa. Kajian yang sudah dirumuskan kemudian ditambahkan dengan pembahasan mengenai teknologi radiasi yang sudah diterapkan, melalui metode dan hasil yang didapatkan. Perumusan teknologi radiasi yang sudah dilakukan menjadi dasar dari pengidentifikasian tantangan dan prospek pengembangan teknologi radiasi sebagai perlakuan pendahuluan biomassa lignoselulosa.

\section{HASIL DAN PEMBAHASAN}

\section{RADIASI GAMMA}

Radiasi gamma ( $\gamma$-ray) adalah radiasi dengan energi sangat tinggi yang terdiri dari photon berenergi tinggi, dengan daya penetrasi dan dihasilkan melalui peluruhan inti atom ketika mereka kembali dari keadaan energi tinggi ke rendah ("peluruhan gamma"). Nuklida radioaktif dari Cobalt-60 dan Cesium137 menghasilkan sinar gamma secara spontan saat mengalami disintegrasi. Pada metode radiasi gamma dengan sumber radiasi Cobalt60, sumber tersebut dimasukkan terlebih dahulu ke dalam tabung tertutup dari logam campuran untuk menghindari kebocoran sinar. Radiasi kemudian segera dipindahkan dari sumber tertutup dan kemudian menyinari biomassa lignoselulosa. Selanjutnya, energi dari radiasi gamma berpindah ke komponenkomponen biomassa melalui tumbukan radiasi dengan atom-atomnya. Energi yang sama masuk ke dalam atom-atom karbon, hidrogen, dan oksigen pada polimer biomassa. Tumbukan-tumbukan tersebut menghasilkan kehilangan elektron pada atom-atom yang menyebabkan ionisasi. Berbagai macam radikal-radikal dengan umur panjang dan pendek terbentuk. Perubahan struktur biomassa terjadi akibat cross-linking dan pemotongan rantai molekuler dalam polimer lignoselulosa. Polisakarida dari selulosa dan pati terdegradasi oleh pemutusan ikatan glikosidik. Radiasi gamma dengan dosis tinggi mampu mendepolimerisasi atau mendelignifikasi konstituen dinding sel lignoselulosa [10].

Teknologi radiasi ion seperti iradiasi berkas elektron dan radiasi gamma dapat menghasilkan ionisasi pada sebuah material dan kemudian menginisiasi reaksi-reaksi kimia dan memutus ikatan kimianya, yang dapat meningkatkan minat dan aplikasi pemanfaatan teknologi tersebut beberapa tahun terakhir ini. Prinsip utama perlakuan pendahuluan ini adalah meradiasi bahan lignoselulosa sehingga 


\section{JURNAL FORUM NUKLIR (JFN), VOLUME 11, NOMOR 2, NOVEMBER 2017}

menghasilkan radikal-radial bebas dalam makromolekul selulosa, dan terjadi degradasi sekunder melalui reaksi kimia seperti pemotongan rantai, cross-linking, dan sebagainya. Ketika bahan lignoselulosa disinari dengan radiasi gamma, komponen selulosa, hemiselulosa dan lignin memiliki kemungkinan terpengaruh oleh radiasi. Lignin adalah bahan polyphenolic yang dapat mempengaruhi reaksi radikal secara signifikan melalui interaksi melalui interaksi transfer muatan antar-molekul [11].

Beberapa penelitian dalam perlakuan pendahuluan terhadap biomassa lignoselulosa disajikan pada Tabel 1. Beberapa penelitian mengkombinasikan radiasi gamma dengan perlakuan kimia-fisik yang lain seperti steam explosion dan penambahan asam dan basa seperti $\mathrm{NaOH}$ dan $\mathrm{H}_{2} \mathrm{SO}_{4}$.

Tabel. 1. Efek Radiasi Gamma terhadap Biomassa Lignoselulosa

\begin{tabular}{|c|c|c|c|c|c|}
\hline No & $\begin{array}{c}\text { Biomassa } \\
\text { Lignoselulosa }\end{array}$ & Kondisi Perlakuan & Perubahan Struktur & Hasil & Referensi \\
\hline 1. & Jerami gandum & $\begin{array}{c}\text { Iradiasi gamma } 100 \text { kGy, } \\
\text { dilanjutkan pemanasan } \\
10 \text { gr jerami padi dalam } \\
100 \mathrm{ml} \mathrm{NaOH} 2 \% \text { selama } 1 \\
\text { jam }\end{array}$ & $\begin{array}{l}\text { Meningkatkan kelarutan } \\
\text { hemiselulosa dan lignin, } \\
\text { meningkatkan permukaan } \\
\text { akses, serta meningkatkan } \\
\text { reksi hidrolisis enzimatik }\end{array}$ & $\begin{array}{c}\text { Yield gula } \\
\text { tereduksi } \\
72,67 \%\end{array}$ & [11] \\
\hline 2. & Serbuk gergaji & Iradiasi gamma $300 \mathrm{kGy}$ & $\begin{array}{c}\text { Memecah ikatan gugus } \\
\text { karboksil dan karbonil pada } \\
\text { sel selulosa }\end{array}$ & $\begin{array}{c}\text { Yield gula } \\
\text { tereduksi } 519 \\
\mathrm{mg} / \mathrm{g}\end{array}$ & {$[12]$} \\
\hline 3. & $\begin{array}{l}\text { Jerami gandum } \\
\text { (Triticum } \\
\text { aestivum L.) }\end{array}$ & $\begin{array}{l}\text { Pemanasan } 50 \text { gr sampel } \\
\text { dalam larutan } \mathrm{H}_{2} \mathrm{SO}_{4} 3 \% \\
\text { pada } 121^{\circ} \mathrm{C} \text { selama } 1 \text { jam, } \\
\text { dilanjutkan dengan iradiasi } \\
\text { gamma } 1000 \mathrm{kGy}\end{array}$ & $\begin{array}{l}\text { Merusak kristalinitas } \\
\text { selulosa, merubah struktur } \\
\text { polimer lignin dan } \\
\text { menghilangkan } \\
\text { hemiselulosa }\end{array}$ & $\begin{array}{c}\text { Yield gula } \\
\text { tereduksi } \\
69,7 \%\end{array}$ & [13] \\
\hline 4. & Jerami padi & Iradiasi gamma 800 kGy & $\begin{array}{l}\text { Merusak matriks selulosa, } \\
\text { hemiselulosa, dan lignin }\end{array}$ & $\begin{array}{l}\text { Yield gula } \\
\text { tereduksi } \\
90,3 \mathrm{mg} / \mathrm{g}\end{array}$ & {$[14]$} \\
\hline 5. & $\begin{array}{l}\text { Softwood } \\
\text { (Triplochiton } \\
\text { scleroxylon) }\end{array}$ & $\begin{array}{l}\text { Iradiasi gamma } 40 \mathrm{kGy} \text {, } \\
\text { dilanjutkan perendaman } \\
\text { dalam larutan } \mathrm{NaOH} 1 \% \\
\text { (rasio 1:10) selama } 2 \text { jam } \\
\text { pada temperatur ruang }\end{array}$ & Mereduksi lignin & $\begin{array}{l}\text { Yield gula } \\
\text { tereduksi } \\
\text { softwood } \\
67,3 \%\end{array}$ & {$[15]$} \\
\hline 6. & $\begin{array}{c}\text { Hardwood } \\
\text { (Khaya } \\
\text { senegalensis) }\end{array}$ & $\begin{array}{l}\text { Iradiasi gamma } 90 \text { kGy } \\
\text { dilanjutkan perendaman } \\
\text { dalam larutan } \mathrm{NaOH} 1 \% \\
\text { (rasio } 1: 10 \text { ) selama } 2 \text { jam } \\
\text { pada temperatur ruang }\end{array}$ & Memotong serat & $\begin{array}{l}\text { Yield gula } \\
\text { tereduksi } \\
\text { hardwood } \\
80,3 \%\end{array}$ & [15] \\
\hline 7. & $\begin{array}{l}\text { Kepingan kayu } \\
\text { (wood chip) }\end{array}$ & $\begin{array}{l}\text { Pemanasan sampel dalam } \\
\text { larutan } 10 \mathrm{~g} / \mathrm{L} \mathrm{NaOH}, \\
\text { dilanjutkan dengan iradiasi } \\
\text { gamma } 200 \mathrm{kGy}\end{array}$ & tidak diteliti & $\begin{array}{c}\text { Yield gula } \\
\text { tereduksi } \\
13,4 \mathrm{~g} / \mathrm{L}\end{array}$ & {$[16]$} \\
\hline 8. & Kulit jeruk & Iradiasi gamma 3500 kGy & $\begin{array}{c}\text { Memutuskan rantai selulosa } \\
\text { dan hemiselulosa }\end{array}$ & $\begin{array}{c}\text { Yield gula } \\
\text { tereduksi } \\
18,4 \mathrm{~g} / \mathrm{g}\end{array}$ & [17] \\
\hline
\end{tabular}


Beberapa tulisan mengenai penggunaan iradiasi gamma pada biomassa lignoselulosa melaporkan bahwa iradiasi gamma dalam dosis tinggi pada biomassa lignoselulosa dapat mengakibatkan penurunan konstituen dinding sel atau mendepolimerisasi dan mendelignifikasi serat. Selain itu, radiasi ion juga mendorong degradasi polisakarida seperti pati, selulosa, dan pektin melalui pemutusan ikatan glikosidik. Kelebihan dasar dari degradasi polimer oleh radiasi termasuk kemampuan untuk mempromosikan perubahan struktur tanpa penambahan reagen kimia atau kebutuhan akan peralatan khusus, maupun pengaturan khusus untuk mengontrol suhu, lingkungan, dan zat tambahan lainnya. Teknologi ini lebih sederhana dan lebih ramah lingkungan daripada metode konvensional lainnya [17].

Wang dkk [14] meneliti pengaruh iradiasi gamma terhadap jerami padi yang menghasilkan permukaan material tidak rata dan ditutupi dengan tetesan kecil, yang dianggap berasal dari lelehan lignin akibat radiasi gamma pada dosis $1000 \mathrm{kGy}$. Perlakuan pendahuluan iradiasi gamma menyebabkan perubahan struktur ultra, pemisahan komponen dinding sel dan peningkatan porositas. Selain itu, iradiasi gamma juga dapat menghilangkan lignin, hal ini dapat dilihat dengan jelas karena hasil perlakuan pendahuluan memiliki permukaan kasar dan area reaktif yang besar, yang sangat penting jika substrat selanjutnya digunakan untuk hidrolisis enzimatik. Perlakuan pendahuluan dengan iradiasi gamma terbukti dapat merusak serat, dan meningkatkan area reaktif yang bermanfaat untuk meningkatkan aksesibilitas selulase. Hal ini tentunya sangat bermanfaat untuk industrialisasi bioetanol dari bahan lignoselulosa yang selama ini masih terkendala rendahnya efisiensi selulase sebagai akibat dari kuatnya struktur selulosa [14].

Dengan adanya penelitian yang disajikan pada Tabel 1, maka iradiasi gamma telah terbukti menjadi salah satu metode yang efisien untuk perlakuan pendahuluan biomassa lignoselulosa. Selain itu, kombinasi iradiasi gamma dengan penambahan asam atau basa maupun dengan perlakuan steam explosion juga dapat menjadi pilihan untuk dapat mengoptimalkan perolehan gula tereduksinya. Pengaruh iradiasi gamma ini masih menarik dan potensial untuk dikembangkan dengan bahan baku berbeda sebagai perlakuan pendahuluan biomassa lignoselulosa yang ramah lingkungan.

\section{IRADIASI BERKAS ELEKTRON}

Iradiasi Berkas Elektron (Electron Beam Radiation) adalah proses pemaparan material target pada akselerator aliran elektron yang sangat bermuatan. Energi kinetik dari elektron yang bergerak bertanggung jawab atas energi tinggi yang dibawa oleh sinar. "Akselerator berkas elektron" adalah perangkat yang biasa digunakan untuk iradiasi berkas elektron. Aliran elektron dipancarkan dari sumber atau electron gun. Pemfokusan dimediasi dan diatur oleh fokus magnetik dan sistem defleksi. Energi elektron dapat dimodulasi dengan memvariasikan dosis iradiasi. Iradiasi berkas elektron pada biomassa lignoselulosa menunjukkan beberapa efek yang agak mirip dengan radiasi pengion lainnya. Studi telah menunjukkan bahwa interaksi berkas elektron berenergi tinggi menyebabkan depolimerisasi selulosa sebagai akibat dari pemotongan rantai. Polimer juga dimodifikasi secara kimia karena efek pengoksidasi dari berkas elektron. Ikatan hidrogen terputus antara rantai selulosa sehingga struktur lebih amorf, dan menyebabkan penurunan kristalinitas, sehingga terjadi pengurangan kekuatan mekanik, dan meningkatkan kelarutan dan reaktivitas selulosa. Iradiasi juga menghasilkan banyak radikal bebas, yang selanjutnya membantu kerusakan struktur akibat radiasi. Cross-linking juga terlihat pada polimer saat iradiasi dengan berkas elektron [9]. Beberapa penelitian dalam perlakuan pendahuluan terhadap biomassa lignoselulosa disajikan pada Tabel 2. Beberapa penelitian tersebut mengkombinasikan iradiasi berkas elektron dengan penambahan larutan asam atau basa. 
Tabel. 2. Efek Iradiasi Berkas Elektron terhadap Biomassa Lignoselulosa

\begin{tabular}{|c|c|c|c|c|c|}
\hline No & $\begin{array}{c}\text { Biomassa } \\
\text { Lignoselulosa }\end{array}$ & Kondisi Perlakuan & Perubahan Struktur & Hasil & Referensi \\
\hline 1. & Jerami padi & $\begin{array}{l}\text { Sampel direndam dalam } \\
\mathrm{NaOH} 4 \% \text { ( } 30 \% \text { dari berat } \\
\text { sampel), lalu diiradiasi } \\
\text { berkas elektron dengan } \\
\text { dosis } 50 \text { Mrad }\end{array}$ & $\begin{array}{l}\text { Memotong rantai selulosa } \\
\text { dan hemiselulosa, } \\
\text { mempermudah akses enzim } \\
\text { terhadap selulosa, } \\
\text { menghilangkan lignin }\end{array}$ & $\begin{array}{l}\text { Yield gula } \\
\text { tereduksi } \\
\quad 35 \%\end{array}$ & [18] \\
\hline 2. & Rumput gajah & $\begin{array}{l}150 \text { gr sampel direndam } \\
\text { dalam } 300 \text { ml larutan } \\
\mathrm{NaOH} 1 \% \text {, kemudian } \\
\text { diiradiasi berkas elektron } \\
\text { dengan dosis } 150 \mathrm{kGy}\end{array}$ & $\begin{array}{l}\text { Mengurangi kristalinitas } \\
\text { selulosa, mempermudah } \\
\text { akses enzim terhadap } \\
\text { selulosa }\end{array}$ & $\begin{array}{l}\text { Yield gula } \\
\text { tereduksi } \\
\quad 40 \%\end{array}$ & [19] \\
\hline 3. & Jerami padi & $\begin{array}{l}\text { Iradiasi berkas elektron } \\
\text { pada } 200-500 \mathrm{kGy}, \\
\text { dilanjutkan dengan } \\
\text { pemanasan sampel dalam } \\
\mathrm{H}_{2} \mathrm{SO}_{4} 3 \% \text { (rasio } 1: 19 \text { ) pada } \\
120^{\circ} \mathrm{C} \text { selama } 1 \text { jam }\end{array}$ & $\begin{array}{c}\text { Mengubah struktur } \\
\text { hemiselulosa dan lignin, } \\
\text { memperluas akses selulosa }\end{array}$ & $\begin{array}{c}\text { Yield gula } \\
\text { tereduksi } \\
92 \%\end{array}$ & {$[20]$} \\
\hline 4. & $\begin{array}{l}\text { Rami (Cannabis } \\
\text { sativa L.) }\end{array}$ & $\begin{array}{l}\text { Iradiasi berkas elektron } \\
\text { pada } 450 \mathrm{kGy} \text {, dilanjutkan } \\
\text { dengan pemanasan } \\
\text { sampel dalam } \mathrm{NaOH} 1 \% \\
\text { pada } 100^{\circ} \mathrm{C} \text { selama } 1 \text { jam }\end{array}$ & $\begin{array}{l}\text { Mempermudah akses enzim } \\
\text { terhadap hemiselulosa }\end{array}$ & $\begin{array}{c}\text { Yield xilosa } \\
18,4 \%\end{array}$ & [21] \\
\hline 5. & Jerami padi & $\begin{array}{l}\text { Iradiasi berkas elektron } \\
\text { pada } 500 \mathrm{kGy} \text {, dilanjutkan } \\
\text { dengan pemanasan } \\
\text { sampel dalam } \mathrm{NaOH} 3 \% \\
\text { pada } 100^{\circ} \mathrm{C} \text { selama } 5 \text { jam }\end{array}$ & $\begin{array}{l}\text { Depolimerisasi lignin dan } \\
\text { sebagian hemiselulosa, } \\
\text { meningkatkan akses enzim } \\
\text { terhadap selulosa }\end{array}$ & $\begin{array}{l}\text { Yield gula } \\
\text { tereduksi } \\
\quad 77 \%\end{array}$ & {$[22]$} \\
\hline 6. & Jerami gandum & $\begin{array}{l}\text { Iradiasi berkas elektron } \\
\text { pada } 100 \mathrm{kGy}\end{array}$ & $\begin{array}{l}\text { Menurunkan kristalinitas } \\
\text { selulosa, mengubah } \\
\text { struktur lignin, merusak } \\
\text { hemiselulosa }\end{array}$ & $\begin{array}{c}\text { Yield gula } \\
\text { tereduksi } \\
74,9 \%\end{array}$ & [7] \\
\hline 7. & Jerami padi & $\begin{array}{c}\text { Sampel direndam dalam } \\
\text { air dengan rasio } 100 \% \text { lalu } \\
\text { diiradiasi berkas elektron } \\
\text { pada } 80 \mathrm{kGy}\end{array}$ & $\begin{array}{l}\text { Mengubah kristalinitas, } \\
\text { memutus rantai selulosa }\end{array}$ & $\begin{array}{l}\text { Yield gula } \\
\text { tereduksi } \\
70,4 \%\end{array}$ & [23] \\
\hline
\end{tabular}

Byoung dkk [20] meneliti pengaruh iradiasi berkas elektron pada jerami padi dan menemukan bahwa yield gula total semakin meningkat dengan meningkatnya dosis radiasi pada kisaran 50-300kGy saat dikombinasikan dengan penambahan larutan $\mathrm{H}_{2} \mathrm{SO}_{4}$. Namun, penghilangan hemiselulosa tidak meningkat saat dosis radiasi lebih dari $200 \mathrm{kGy}$. Hasil ini mengkonfirmasi bahwa iradiasi berkas elektron secara selektif meningkatkan penghilangan hemiselulosa, dan efektif dan mudah dikontrol untuk mendapatkan hasil glukosa tinggi [20].

Dari beberapa penelitian yang disajikan pada Tabel 2, maka iradiasi berkas elektron telah terbukti menjadi salah satu metode yang patut dipertimbangkan untuk perlakuan pendahuluan biomassa lignoselulosa. Setiap perlakuan pendahuluan yang efektif harus cepat andal, berkelanjutan dan ramah lingkungan. Iradiasi berkas elektron mempunyai lingkup luas untuk dimanfaatkan dan dimodifikasi sebagai perlakuan pendahuluan biomassa lignoselulosa. Di balik kekhawatiran tentang biaya dan efektivitasnya, faktor-faktor lain seperti kelestarian lingkungan dan permintaan bahan bakar dan bahan kimia yang terus meningkat di masa depan akan mendorong upaya penelitian tentang pemanfaatan iradiasi berkas elektron, mengingat besarnya nilai tambah yang dapat dihasilkan dari biomassa lignoselulosa [19]. 


\section{TEKNOLOGI RADIASI LAINNYA}

Selain radiasi gamma dan iradiasi berkas elektron, beberapa penelitian juga mengaplikasikan teknologi radiasi lainnya sebagai perlakuan pendahuluan pada biomassa lignoselulosa, diantaranya adalah iradiasi ultrasonik, radiasi microwave dan iradiasi UV.

Lopes dkk membuktikan teknologi radiasi microwave dan ultrasonik dapat menghemat waktu perlakuan pendahuluan dibandingkan dengan pemanasan biasa. Radiasi tersebut dapat mempermudah akses bahan kimia untuk mendegradasi komponen lignoselulosa karena menyebabkan depolimerisasi dari lignin dan ikatan hidrogen [24].

Microwave adalah suatu gelombang elektromagnetik dengan frekuensi $300 \mathrm{MHz}$ sampai $300 \mathrm{GHz}$ [2]. Perlakuan pendahuluan biomassa lignoselulosa dengan radiasi microwave didasarkan pada efek non-termal dan termal dari gelombang mikro. Radiasi microwave memberikan perubahan dinamis pada lignin, hemiselulosa, dan selulosa [9]. Radiasi microwave dipengaruhi oleh intensitas, waktu iradiasi dan konsentrasi substrat biomassa [25]. Rosyidin dkk meiradiasi $40 \mathrm{gr}$ bubuk batang pisang yang dicampur $500 \mathrm{ml}$ $\mathrm{NaOH} 0,5 \mathrm{M}$ dengan daya microwave 950 watt selama 40 menit dan menghasilkan yield selulosa $27,265 \%$, hemiselulosa $17,86 \%$ dan lignin $3,26 \%$ [26].

Iradiasi ultrasonik pada biji lobak dapat menurunkan temperatur dan konsentrasi $\mathrm{NaOH}$ pada perlakuan pendahuluan untuk meningkatkan hidrolisis enzim [27]. Ultrasonik dapat membantu delignifikasi dari berbagai lignoselulosa, bahkan saat dikombinasikan dengan basa dapat meningkatkan delignifikasi menjadi hampir 2 kali lipat daripada radiasi microwave [28]. Kombinasi 3\% larutan $\mathrm{H}_{2} \mathrm{SO}_{4}$ dengan ultrasonik pada level amplitudo 60 $(127 \mathrm{~W})$ dapat menghasilkan produksi etanol hingga $820 \mathrm{mg} / \mathrm{L}$ dari ampas tebu [29]. Perlakuan pendahuluan dengan kombinasi $\mathrm{NaOH}$ dan iradiasi ultrasonik secara efektif merusak ikatan hidrogen intermolekuler pada lignoselulosa sehingga menurunkan kristalinitas selulosa [30].

Muller dkk membuktikan iradiasi sinar UV pada panjang gelombang $280 \mathrm{~nm}$ dapat memodifikasi struktur kayu dengan mendegradasi lignin. Intensitas sinar UV yang terserap pada permukaan kayu dipengaruhi oleh panjang gelombang, distribusi intensitas, dan spektrum absorbsi lignin [31]. Iradiasi sinar UV mengakibatkan peningkatan digestibilitas dinding sel barley (jelai) karena terlarutnya lignin menjadi pentosa [32].

\section{STATUS DAN TANTANGAN SAAT INI}

Digestibilitas biomassa selulosa telah ditingkatkan dengan menggunakan metode radiasi energi tinggi, yaitu radiasi gamma, iradiasi berkas elektron, radiasi microwave, ultrasonik, dan radiasi UV. Metode yang mendasari radiasi energi tinggi dapat berupa satu atau lebih perubahan fitur biomassa selulosa, termasuk peningkatan luas permukaan spesifik, penurunan derajat polimerisasi dan kristalinitas selulosa, hidrolisis hemiselulosa, dan depolimerisasi parsial lignin [33]. Secara umum, iradiasi bebas dari toksisitas karena reagen atau aditif tidak diperlukan, menjadikannya lebih ramah lingkungan dan lebih sederhana dibandingkan dengan metode konvensional seperti asam dan hidrolisis alkali. Selain itu, radiasi memiliki kemampuan untuk menyebabkan degradasi polimer yang dapat direproduksi dan kuantitatif [34]. Iradiasi tidak melibatkan penggunaan pelarut dalam jumlah besar dan menghilangkan kebutuhan pemulihan atau daur ulang. Masalah korosi yang terkait dengan beberapa bahan kimia juga tidak dihadapi selama iradiasi. Salah satu tantangan yaitu pengurangan terbentuknya inhibitor fermentasi diatasi dengan baik pada metode radiasi, serta kebutuhan energi dalam hal panas yang diperlukan untuk penetrasi bahan kimia dapat dihindari. Kebutuhan pendinginan dan netralisasi setelah perlakuan pendahuluan biomassa juga tidak diperlukan [9].

Teknologi iradiasi merupakan teknologi canggih dapat dimanfaatkan sebagai perlakuan pendahuluan biomassa lignoselulosa. Namun, poin-poin tertentu harus dipertimbangkan sebelumnya. Studi penelitian yang dilakukan hingga saat ini berfokus pada iradiasi biomassa pada skala laboratorium saja sehingga diperlukan studi skala percontohan untuk memvalidasi hasil penelitian. Pengembangan teknologi ini untuk dapat diimplementasi secara komersial masih terhambat biaya yang mahal. Selain itu, peraturan keselamatan 
tertentu harus diikuti saat menggunakan radiasi untuk menghindari bahaya kesehatan yang mungkin terjadi [9]. Meskipun keuntungan dari teknologi radiasi ini sudah banyak diteliti dan mendapatkan hasil yang memuaskan, namun pemanfaataannya masih belum luas karena keterbatasan biaya dalam pengembangannya. Sebuah fasilitas radiasi membutuhkan biaya konstruksi yang besar, dan memerlukan petugas yang tersertifikasi dalam pengoperasiannya. Pengembangan ke depan diharapkan mampu memberikan gambaran studi kelayakan dalam penerapan teknologi radiasi sehingga dapat dimanfaatkan secara luas.

\section{Prospek di Masa Depan}

Teknologi iradiasi sebagai perlakuan pendahuluan biomassa lignoselulosa adalah sebuah metode pendekatan baru yang masih relatif kurang dikembangkan. Kebutuhan biaya konstruksi yang besar menjadi tantangan terbesar yang menghambat pengembangan teknologi radiasi. Namun, pengembangan teknologi radiasi ke depan sebagai teknologi yang ramah lingkungan akan tetap menjanjikan untuk meningkatkan nilai tambah dari biomassa lignoselulosa. Studi yang difokuskan pada mekanisme yang terlibat selama penerapan teknologi radiasi terhadap biomassa lignoselulosa perlu dilakukan sebagai upaya mewujudkannya sebagai teknologi komersial. Pemahaman mekanisme ini akan mendorong terwujudnya sebuah perancangan yang mampu memberikan gambaran simulasi sebuah studi optimasi proses. Melalui studi optimasi tersebut, diharapkan sebuah pengembangan mengenai desain reaktor dan optimasi proses serta kelayakan ekonomi dapat diterapkan sebagai upaya pengurangan biaya dan peningkatan efisiensi energi teknologi radiasi. Pada akhirnya, komersialisasi teknologi radiasi ini diharapkan mampu menjadi bagian terintegrasi dari teknologi pemanfaataan biomassa lignoselulosa di masa depan.

\section{KESIMPULAN}

Teknologi radiasi dapat digunakan sebagai perlakuan pendahuluan terhadap biomassa lignoselulosa yang menguntungkan dan ramah lingkungan. Hal ini karena teknologi radiasi dapat meningkatkan efektivitas perlakuan pendahuluan dan mengubah karakteristik komponen-komponen biomassa lignoselulosa. Dengan menggunakan teknologi radiasi, reaksi dapat dioperasikan pada temperatur yang tidak terlalu tinggi dan dengan jumlah bahan kimia yang lebih sedikit daripada perlakuan pendahuluan dengan penambahan bahan kimia tanpa kombinasi teknologi radiasi. Selain itu, teknologi radiasi juga mengurangi kebutuhan energi sehingga membuat proses ini layak untuk dikembangkan. Radiasi merupakan sumber energi yang unik dan penerapan teknologinya dapat memberikan metode yang lebih sederhana, efisien, hemat biaya, dan ramah lingkungan dalam pemanfaatan biomassa lignoselulosa.

\section{DAFTAR PUSTAKA}

1. P. H. NORTH, "METHOD AND SYSTEM FOR FRACTIONATION OF LIGNOCELLULOSIC BIOMASS", US PATENT 8,657,960, 14, 2014.

2. S. TSUBAKI, J.-I. AZUMA, T. YOSHIMURA, M.M. MAITANI, E. SUZUKI, S. FUJII, DAN Y. WADA, "MICROWAVE-INDUCED BIOMASS FRACTIONATION", BIOMASS FRACTIONATION TECHNOLOGIES FOR A LIGNOCELLULOSIC FEEDSTOCK BASED BIOREFINER, ELSEVEIR, PP 103-126, 2016.

3. C. G. YOO, "PRETREATMENT AND FRACTIONATION OF LIGNOCELLULOSIC BIOMASS FOR PRODUCTION OF BIOFUEL AND VALUE-ADDED PRODUCTS", DISERTASI DOKTOR, IOWA STATE UNIVERSITY, 2012.

4. P. F. H. HARMSEN, W. J. J. HUIJGEN, L. M. LOPEZ, R. R. C BERMUDEZ BAKKER, "LITERATURE REVIEW OF PHYSICAL AND CHEMICAL PRETREATMENT PROCESSES FOR LIGNOCELLULOSIC BIOMASS", ENERGY RESEARCH CENTRE OF THE NETHERLANDS, PP 8-14, 2010.

5. E. HEUSER, THE CHEMISTRY OF CELLULOSE, JOHN WILEY \& SONS, 1944.

6. P. KUMAR, DIANE M. BARRETT, MICHAEL J. DELWICHE DAN PIETER STROEVE, "METHODS FOR PRETREATMENT OF 
LIGNOCELLULOSIC BIOMASS FOR EFFICIENT HYDROLYSIS AND BIOFUEL PRODUCTION", ASC PUBLICATIONS INDUSTRIAL AND ENGINEERING CHEMISTRY RESEARCH, PP C-M, 2009.

7. B. YEOUP, C. JAE, T. LEE, S. SIK, AND L. U. KIM, "A COMPARISON OF THE EFFICIENCY OF ELECTRON BEAM IRRADIATION ON ENZYMATIC HYDROLYSIS BETWEEN 4 DOSES OF $25 \mathrm{KGY}$ AND A SINGLE DOSE OF 100 KGY FOR BIOETHANOL PRODUCTION,", J KOREAN SOC APPL BIOL CHEM, PP. 385-389, 2012.

8. G. BRODEUR, E. YAU, K. BADAL, J. COLLIER, K. B. RAMACHANDRAN, AND S. RAMAKRISHNAN, "CHEMICAL AND PHYSICOCHEMICAL

PRETREATMENT OF LIGNOCELLULOSIC BIOMASS: A REVIEW,” ENZYME RES., VOL. 2011, PP. 1-17, 2011.

9. A. SAINI, N. K. AGGARWAL, A. SHARMA, AND A. YADAV, "PROSPECTS FOR IRRADIATION IN CELLULOSIC ETHANOL PRODUCTION," BIOTECHNOL. RES. INT., VOL. 2015, PP. 1-13, 2015.

10. S. BEHERA, R. ARORA, N. NANDHAGOPAL, AND S. KUMAR, "IMPORTANCE OF CHEMICAL PRETREATMENT FOR BIOCONVERSION OF LIGNOCELLULOSIC BIOMASS," RENEW. SUSTAIN. ENERGY REV., VOL. 36, PP. 91-106, 2014.

11. Y. YIN AND J. WANG, "ENHANCEMENT OF ENZYMATIC HYDROLYSIS OF WHEAT STRAW BY GAMMA IRRADIATION - ALKALINE PRETREATMENT," RADIAT. PHYS. CHEM., VOL. 123, PP. 63-67, 2016.

12. Y. XIANG, Y. XIANG, AND L. WANG, "BIORESOURCE TECHNOLOGY COBALT-60 GAMMA-RAY IRRADIATION PRETREATMENT AND SLUDGE PROTEIN FOR ENHANCING ENZYMATIC SACCHARIFICATION OF HYBRID POPLAR SAWDUST," BIORESOUR. TECHNOL., VOL. 221, PP. 9-14, 2016.
13. S. HYUN ET AL., "IMPROVED ENZYMATIC HYDROLYSIS OF WHEAT STRAW BY COMBINED USE OF GAMMA RAY AND DILUTE ACID FOR BIOETHANOL PRODUCTION," RADIAT. PHYS. CHEM., VOL. 94, PP. 231-235, 2014.

14. K. WANG, X. XIONG, J. CHEN, L. CHEN, AND X. SU, "COMPARISON OF GAMMA IRRADIATION AND STEAM EXPLOSION PRETREATMENT FOR ETHANOL PRODUCTION FROM AGRICULTURAL RESIDUES," BIOMASS AND BIOENERGY, VOL. 46, PP. 301-308, 2012.

15. E. BETIKU, T. V OJUMU, AND B. O. SOLOMON, "A COMPARATIVE STUDY OF THE HYDROLYSIS OF GAMMA IRRADIATED LIGNOCELLULOSES," VOL. 26, NO. 02, PP. 251-255, 2009.

16. S. KIM, J. CHOI, M. JOE, AND J. KIM, "EFFECT OF GAMMA IRRADIATION ON WOOD CHIP SACCHARIFICATION PRETREATED WITH NAOH," VOL. 54, NO. 3, PP. 431-435, 2016.

17. R. S. OROZCO ET AL., "GAMMA IRRADIATION INDUCED DEGRADATION OF ORANGE PEELS," PP. 3051-3063, 2012.

18. L. Z. XIN, "EFFECT OF RADIATION PRETREATMENT ON ENZYMATIC OF ALKALI SOLUTION," VOL. 43, PP. 1317, 1993.

19. K. KARTHIKA, A. B. ARUN, AND P. D. REKHA, "ENZYMATIC HYDROLYSIS AND CHARACTERIZATION OF LIGNOCELLULOSIC BIOMASS EXPOSED TO ELECTRON BEAM IRRADIATION," CARBOHYDR. POLYM., VOL. 90, NO. 2, PP. 1038-1045, 2012.

20. B. LEE, J. LEE, P. KANG, S. HONG, AND J. JEUN, "IMPROVED PRETREATMENT PROCESS USING AN ELECTRON BEAM FOR OPTIMIZATION OF GLUCOSE YIELD WITH HIGH SELECTIVITY," PP. 15481557, 2014.

21. S. SHIN AND Y. JOO, "IMPROVING ENZYMATIC HYDROLYSIS OF INDUSTRIAL HEMP (CANNABIS SATIVA L.) BY ELECTRON BEAM 
IRRADIATION," VOL. 77, PP. 10341038, 2008.

22. D. K. B. LEE AND J. L. P. KANG, "ELECTRON BEAM IRRADIATION AND DILUTE ALKALI PRETREATMENT FOR IMPROVING SACCHARIFICATION OF RICE STRAW," VOL. 57, 2014.

23. J. S. BAK, "PROCESS EVALUATION OF ELECTRON BEAM IRRADIATIONBASED BIODEGRADATION RELEVANT TO LIGNOCELLULOSE BIOCONVERSION," PP. 1-7, 2014.

24. M. ANDRE, C. LOPES, K. G. JOÃO, A. R. C. MORAIS, E. B.- Ł, AND R. B.- Ł, "IONIC LIQUIDS AS A TOOL FOR LIGNOCELLULOSIC BIOMASS FRACTIONATION," 2013.

25. F. WOLDESENBET AND A. P. VIRK, "EFFECT OF MICROWAVE IRRADIATION ON XYLANASE PRODUCTION FROM WHEAT BRAN AND BIOBLEACHING OF EUCALYPTUS KRAFT PULP," PP. 100108, 2012.

26. K. ROSYIDIN, Y. KHAHARUDIN, R. AMIN, N. K. ANDRIANI, AND D. M. MAHARANI, "ASSISTED PRETREATMENT WITH MICROWAVE HEATING UNTUK PENINGKATAN KADAR SELULOSA BATANG PISANG PADA PRODUKSI BIOETANOL," VOL. 2015, NO. SNIPS, PP. 33-36, 2015.

27. K. EOP, K. G. JEONG, AND D. PARK, "RAPESEED-STRAW ENZYMATIC DIGESTIBILITY ENHANCEMENT BY SODIUM HYDROXIDE TREATMENT UNDER ULTRASOUND IRRADIATION,” PP. 1019-1029, 2013.

28. P.B. SUBHEDAR, P.R. GOGATE, "USE OF ULTRASOUND FOR PRETREATMENT OF BIOMASS AND SUBSEQUENT HYDROLYSIS AND FERMENTATION", PP. 127-149, 2016.

29. M. KANDASAMY ET $A L$, "INVESTIGATION OF ETHANOL PRODUCTION POTENTIAL FROM LIGNOCELLULOSIC MATERIAL WITHOUT ENZYMATIC.”, 2017.

30. M. KARIMI, B. JENKINS, AND P. STROEVE, "ULTRASOUND IRRADIATION IN THE PRODUCTION OF ETHANOL FROM BIOMASS,"
RENEW. SUSTAIN. ENERGY REV., VOL. 40, PP. 400-421, 2014.

31. M. SCHWANNINGER, M. STEINER, AND H. ZOBL, "YELLOWING AND IRCHANGES OF SPRUCE WOOD AS RESULT OF UV-IRRADIATION," VOL. 69, PP. 97-105, 2003.

32. J. A. MCCALLUM, J. T. ARNASON, I. E. P. TAYLOR, AND G. H. N. TOWERS, "EFFECTS OF UV-IRRADIATION ON ENZYMIC DIGESTION OF BARLEY COLEOPTILE CELL WALLS," J. PLANT PHYSIOL., VOL. 139, NO. 6, PP. 641646, 1992.

33. Y. ZHENG, Z. PAN, AND R. ZHANG, "OVERVIEW OF BIOMASS PRETREATMENT FOR CELLULOSIC ETHANOL PRODUCTION," VOL. 2, NO. 3, PP. 51-68, 2009.

34. Y. L. TA, Y. WU, G. HOA, AND Y. JAMALIAH, "ROLE OF ENERGY IRRADIATION IN AIDING PRETREATMENT OF LIGNOCELLULOSIC BIOMASS FOR IMPROVING REDUCING SUGAR RECOVERY," CELLULOSE, NO. 2012, 2016. 